\title{
Genetic variation of the riparian pioneer tree species Populus nigra L. I. Study of population structure based on isozymes
}

\author{
AGNÈS LEGIONNET* $†$ \& FRANÇOIS LEFÈVRE $\ddagger$ \\ †INRA, Station d'Amélioration des Arbres Forestiers, 45160 Ardon and $\ddagger$ INRA, Unité de recherches forestières \\ méditerranéennes, Avenue Vivaldi, 84000 Avignon, France
}

\begin{abstract}
Eight polymorphic isozyme loci were used to describe the level and organization of the genetic diversity in Populus nigra L. over 111 sites in France and among 60 additional individuals from throughout the species range. Best descriptors and estimators of gene diversity and differentiation were sought. Overall diversity level was found to be comparable to other widespread species. Differentiation at three geographical scales was low, although local allele fixations indicated limitation of gene flow. Inferences were made on the effect of the natural history of the species on the organization of neutral diversity, and recommendations for collection of genetic resources were derived.
\end{abstract}

Keywords: genetic diversity, genetic resources, isozymes, population structure, Populus nigra.

\section{Introduction}

The European black poplar, Populus nigra L., is a common pioneer tree in riparian forests, ranging from central and southern Europe to central Asia and north Africa (Zsuffa, 1974). Scattered individuals and small stands also occupy upland sites. Some clones of $P$. nigra are widely used for ornamental purposes, and as screens against wind. Although the use of pure $P$. nigra for wood production is rare, the species is found among the ancestors of 63 per cent of the poplar cultivars registered by the International Poplar Commission, mainly in interspecific hybrid clones with $P$. deltoides (Viart, 1992). The genetic diversity of the species is thought to be threatened in two different ways. First, the reduction of perturbed areas arising from the regularization of river flows has been decreasing the regeneration of this species all over western Europe (Frison et al., 1995). Secondly, gene exchanges between the wild and the cultivated gene pool may also occur spontaneously (Cagelli \& Lefèvre, 1995), and a wide distribution of a small number of clones, likely to intercross with wild trees, may lead to a reduction of genetic diversity. However, the markers we used were not suitable tools for a study of introgression, because the alleles from $P$. deltoides could not be

*Correspondence.

(C)1996 The Genetical Society of Great Britain. distinguished for sure from the rare alleles of $P$. nigra, and thus we will not be able to discuss this question. In this study, we measured gene diversity and differentiation of $P$. nigra in France by means of allozyme variation. We tried to observe the effect of the species singularities on its neutral genetic diversity, and we discuss the consequences for the sampling of genetic diversity.

\section{Material and methods}

This study was carried out on a stool-bed collection of individual trees held by INRA in Orléans. Genotypes were gathered over a period of 20 years by different collectors (Teissier du Cros, 1977; Duval et al., 1993). For most of the accessions, cuttings had been collected from adult trees. In other cases, seeds were collected and half-sib families were vegetatively propagated. Only one randomly chosen offspring of each family was included in the analyses.

\section{Collection}

The sample used was made of (1) 60 individual trees representing different countries from the species range, namely Bulgaria (6 individuals), Romania (18), Slovakia (7), Hungary (5), Belgium (12) and Italy (12); (2) 111 individuals representing different collecting sites (Fig. 1) in France, and (3) 196 indi- 


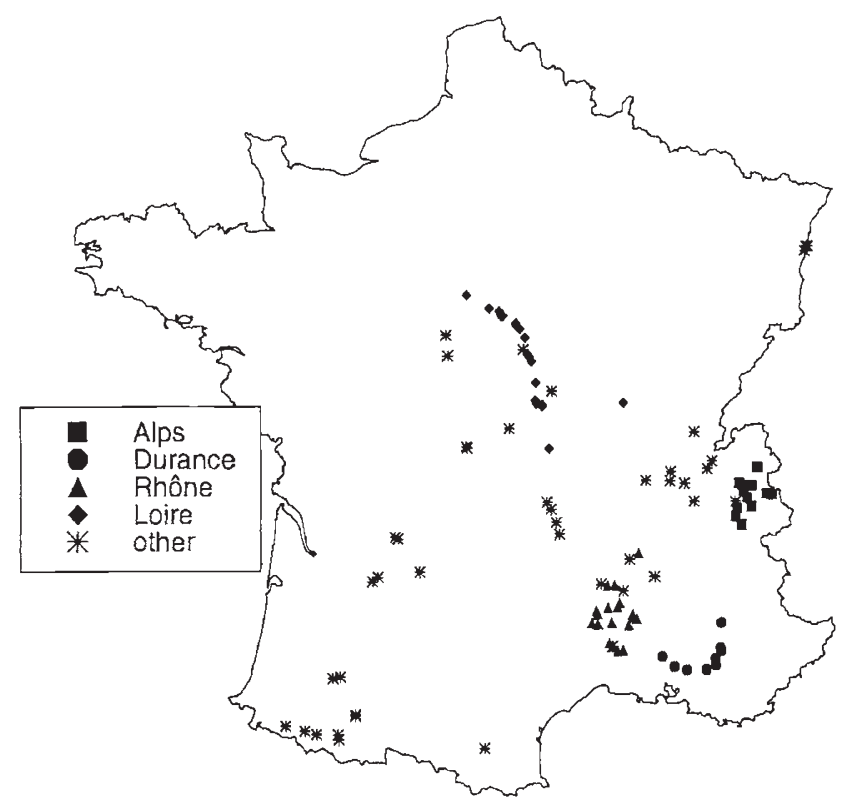

Fig. 1 Map of the sites sampled in France for the study collection of Populus nigra with locations of the four study regions.

viduals representing four sampled stands of large extent: Mallemort $\left(43^{\circ} 44^{\prime} \mathrm{N}, 5^{\circ} 10^{\prime} \mathrm{E}\right)$ in the Durance valley, 50 individuals; Les Brocs $\left(47^{\circ} 28^{\prime} \mathrm{N}, 2^{\circ} 54^{\prime} \mathrm{E}\right)$ in the Loire valley, 32 individuals; Pouilly $\left(47^{\circ} 15^{\prime} \mathrm{N}\right.$, $2^{\circ} 58^{\prime} \mathrm{E}$ ) in the Loire valley, 19 individuals; and Tinte $\left(46^{\circ} 50^{\prime} \mathrm{N}, 3^{\circ} 23^{\prime} \mathrm{E}\right)$ in the Loire valley, 95 individuals.

The stands Tinte and Les Brocs presented separated geographical zones corresponding to age classes: four zones in Tinte (respectively including $51,11,18$, and 15 sampled individuals), and two zones in Les Brocs (16 sampled individuals in each). The distribution of trees into geographical zones was confirmed by observation of aerial pictures. In Tinte, ages were measured approximately with an auger. In both cases, the youngest age classes were found closest to the river bank. Analysis of population structure was carried out at four hierarchical levels provided by this sampling: (i) among countries within the species range: a set representing France made of one randomly chosen genotype per sampled site was compared to the foreign collection; (ii) among regions within France: 249 clones were included, originating from the following four geographical regions: Alps (several drainages in the mountains of the northern Alps), Rhône (several drainages on the right bank of the Rhône), Durance (one drainage in the southern Alps, including the stand Mallemort), Loire (the open and lowland drainage of Loire and Allier, including the stands Tinte, Pouilly and Les Brocs); (iii) among stands within the region Loire; and (iv) among zones within the stand Tinte.

\section{Electrophoresis}

Twigs were collected in winter and stored at $4^{\circ} \mathrm{C}$ until extraction. On each individual, one to five dormant buds were crushed with $0.5 \mathrm{~mL}$ extraction buffer (Tris- $\mathrm{HCl} 0.1 \mathrm{~m}, \mathrm{pH} 7.5,2$ per cent PEG, 0.12 per cent EDTA, 4 per cent soluble PVP), $50 \mathrm{mg}$ insoluble PVP and some sand. Extract was absorbed on $4 \times 6 \mathrm{~mm}$ wicks of Whatman chromatography paper, and stored at $-80^{\circ} \mathrm{C}$. The same protocol was used for leaf extracts from the two youngest leaves of plants growing in the greenhouse. Electrophoresis was carried out on 12 per cent starch gels, with two different buffer systems: lithium-borate (Scandalios, 1969; modified) and morpholine (Clayton \& Tretiak, 1972). Staining was processed according to Bergmann (1987) and Second \& Trouslot (1980), modified. Each individual was assayed for bud and leaf extracts. The EST system was stained only for leaves, and the DIA and SDH systems only for dormant buds. All other systems gave the same results with both kinds of extracts. Eight Mendelian polymorphic loci were scored: Pgm, Sdh, Lap, Got-4, Mdh-1, Dia-2, Idh-1 and Est-r. Inheritance and functional form of enzymes for loci Lap, Got-4, Mdh-1, $S d h$ and $P g m$ have been demonstrated by Rajora (1990) using root-tip extracts. Correspondence between patterns obtained with different organs and repeatability of patterns for clones grown in different conditions were verified by Malvolti et al. (1991). We verified the Mendelian inheritance of loci for the enzyme systems EST, DIA, IDH.

\section{Data analysis}

Allele frequencies, genetic diversity and differentiation parameters were computed using different computer packages: s - PLUs (3.0, Statistical Sciences Inc., Seattle, 1991), GENEPOP (Raymond \& Rousset, 1995) and Biosys (1.7, Swofford \& Selander, 1981).

\section{Allele frequencies}

Population allele frequencies $p_{i}$ were estimated by the sample allele frequencies, and variances were estimated including the sample size and the sample genotypic frequency of homozygotes, according to Weir (1990): this estimate is robust for deviations from Hardy-Weinberg equilibrium (HWE). 


\section{Genetic diversity}

Nei's gene diversity index $H$ (Nei, 1973) originally described for one locus in one infinite random mating population was used to compare gene diversities. For real populations, an unbiased estimate of this parameter, robust to deviation from HWE and to small sample size is given by Weir (1990). Variance of gene diversity depends on allele frequencies, genotypic frequencies and linkage disequilibrium between loci. As pointed out by Fuerst et al. (1977), diversity indices are expected to vary widely among loci. These authors generated the theoretical distribution of observed heterozygosities for different values of the effective population size and the mutation rate. In order to detect abnormal loci or an abnormal distribution of gene diversities, we tested the goodness of fit of the observed distribution of $H$-values in our study to the theoretical distributions with a nonparametrical Smirnov test (Sprent, 1992).

Hardy-Weinberg equilibrium and genotypic linkage equilibrium These measures were tested within the different groups using the GENEPOP software, providing exact probability values (Louis \& Dempster, 1987; Guo \& Thompson, 1992). A 1 per cent probability level was used to test hypotheses of equilibrium.

Differentiation Population structure can be summarized by $F$-statistics, as defined by Wright (1940, 1951 ) for one allele, or by Nei's $G_{\mathrm{ST}}(\mathrm{Nei}, 1973)$ for several alleles at several loci. Under Nei's fixed effect model approach, $G_{\mathrm{ST}}$ describes the proportion of diversity found among populations. Weir and Cockerham (1984) pointed out the difficulty of using $G_{\mathrm{ST}}$ or $F_{\mathrm{ST}}$ to compare different studies, because of the various existing ways to handle small or unequal sample sizes, number of populations, multiple loci and alleles. They defined $f, \mathrm{~F}$ and $\theta$, parameters of a random effect model in which all populations are supposed to have been founded by the same ancestor population, to have the same size and to have differentiated from each other only by genetic drift. $F, f$ and $\theta$ are equivalent to $F_{\mathrm{IT}}, F_{\mathrm{IS}}$ and $F_{\mathrm{ST}}$, respectively. The authors give formulae to compute $F, f$ and $\theta$ as well as the variance of these parameters, taking into account the population structure (HW disequilibrium) and the sampling requirements: used in different studies, their model would allow better comparisons between populations or between species. However, using simulation results, Chakraborty \& Leimar (1987) compared different ways of handling unequal sample sizes in the computation of the differentiation parameter $\left(\mathrm{G}_{\mathrm{ST}}\right.$ or $\left.\theta\right)$. They showed the adequacy of Weir \& Cockerham's weighting scheme (in which the subpopulations are weighted by the sample size) for small values of $G_{\mathrm{ST}}$ $\left(G_{\mathrm{ST}}<0.01\right)$ whereas Nei \& Chesser's (1983) scheme, in which all populations are given the same weight, appeared to be appropriate for greater values of differentiation. In addition, the variation in subpopulation size that occurs in time and space in real populations causes an important source of deviation from Weir \& Cockerham's model. In our case, real population size as defined by the scale of genetic exchange is not easy to estimate, but it seems probable that it will vary between such geographically contrasted sites as the Alps and the Loire valley because of restriction to seed and pollen flow by natural obstacles such as mountains. Estimates and confidence intervals of $f, F$ and $\theta$ for different subdivision levels were computed with the DIPLOIDL program (Weir, 1990), which uses Weir \& Cockerham's estimators. Estimation of $G_{\mathrm{ST}}$ was also computed following Nei \& Chesser (1983).

Genetic distances Genetic distances summarize differences between populations. Nei's genetic distance (1972) and the coancestry distance (Reynolds et al., 1983; Weir, 1990) are based on genetic models supposing panmixia and isolation of subpopulations: these are unworkable assumptions, so that these distances can be regarded more as descriptors of differences. The coancestry distance is more suitable than Nei's distance for short-term divergence (Weir, 1990). Other descriptors of differences are also provided by numerous geometric distances (Lefort-Buson \& De Vienne, 1985). We used the Reynolds coancestry distance (corrected formula in Weir, 1990) and the Gregorius distance (Gregorius, 1974, 1984); the latter among geometric distances fulfils the mathematical requirements of a distance.

\section{Results}

\section{Characterization of sampled loci}

No statistically significant genotypic linkage disequilibrium was found for any pair of loci, and no abnormality was detected in the distribution of single locus heterozygozities: mean heterozygosities per locus range between 0.01 (Got-4) and 0.391 (Dia-2); mean heterozygosity for the species is 0.170 . The hypothesis of identical observed and theoretical distributions was tested with the Smirnov test for 
$H=0.1$ and $H=0.2$ (distributions in Fuerst et al., 1977). It was not rejected at the 5 per cent significance level in either case.

\section{Allele frequencies, gene diversity and genetic distances}

Allele frequencies (Fig. 2) revealed differences between France and foreign countries. Although the estimation variance is great, the foreign sample permits an estimation of allele frequencies for comparison. Most of the rare alleles $(S D H-1$, SDH-4, $M D H-1-1, I D H-1-2, I D H-1-3)$ are less frequent in France than in the whole species range. Loci Dia-2 and Est-r with two common alleles show an inversion of the most frequent allele between France and foreign countries. The only alleles found in France and not in the foreign collection are $S D H-4, G O T-4-2$ and $L A P-1$ : these alleles are present in very low frequencies in the French collection, so that not finding them in the foreign collection may be an effect of restricted sample size $(60$ individuals). Average diversity (Fig. 3 ) is higher in the foreign collection $(H=0.251)$ than in the French $(0.198)$, and than in any region of France represented (0.138-0.230).

Comparison between regions reveals the individuality of the Alps: this region shows higher frequencies of the rare alleles $L A P-1, M D H-1-1$ and EST-r-1, that contribute to the high diversity: 0.230 . The Loire valley differs from other regions by significantly higher frequency of the $S D H-2$ allele, significantly lower representation of EST-r-1 and absence of the rare $M D H-1-1$ allele (although the Loire is
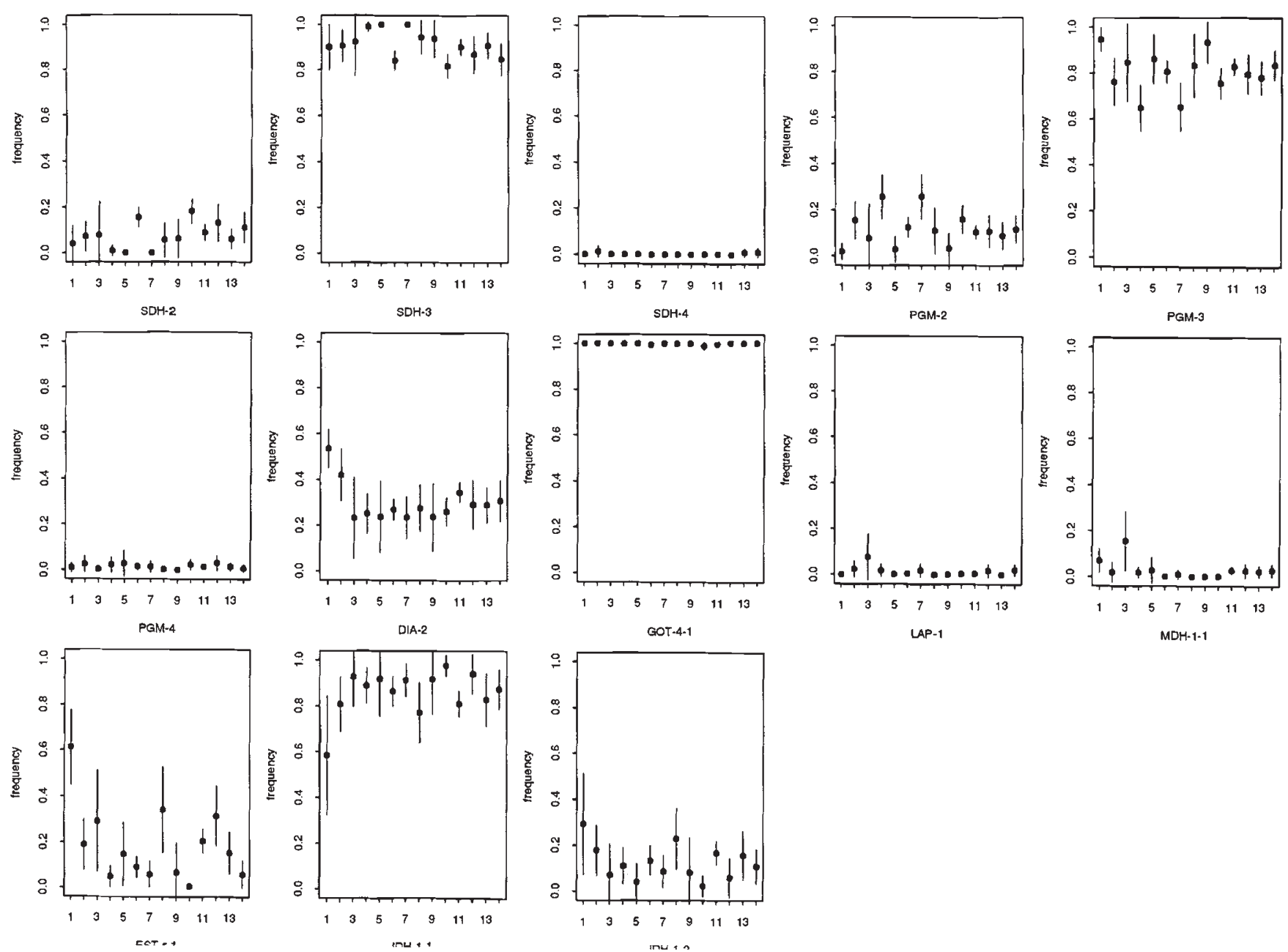

Fig. 2 Allele frequencies in the different geographical groupings of the Populus nigra collection, with 95 per cent confidence intervals. 1, Foreign Countries; 2, France; 3, Alps; 4, Durance; 5, Rhône; 6, Loire; 7, Mallemort; 8, Les Brocs; 9 , Pouilly; 10, Tinte; 11-14, zones 1-4 in Tinte. 
the largest studied sample). The closest region to the Alps with respect to both genetic distances is Rhône (Fig. 4), and the farthest is Durance. Regions Loire and Durance are the closest according to the Gregorius genetic distance, although geographical distance between these two regions is the greatest.

Comparison between the stands of the Loire reveals the heterogeneity of this drainage: significant differences in allele frequencies were found between stands. Concerning diversities, Les Brocs has the highest index among stands $(H=0.204)$, and Pouilly the lowest $(H=0.115)$. Coexistence of two age classes in Les Brocs, if they represent two different origins, could explain the high value of $H$ : when the

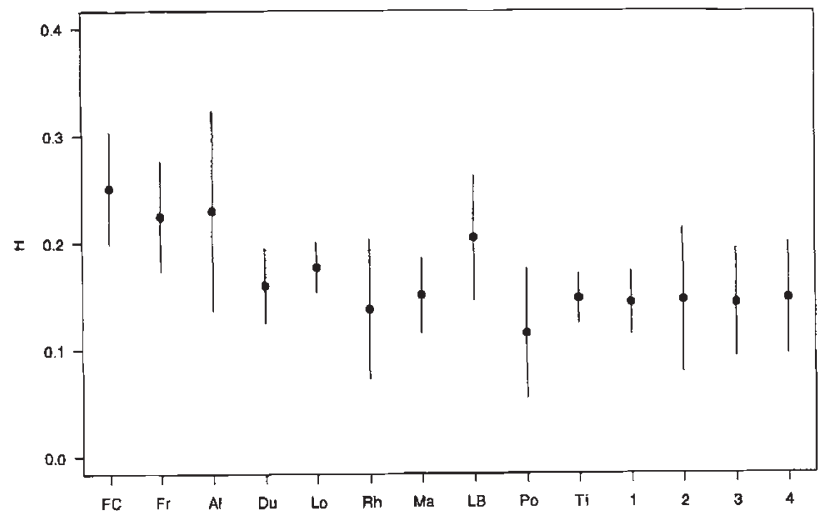

Fig. 3 Average gene diversity in the different geographical groupings of the Populus nigra collection with 95 per cent confidence intervals. FC, Foreign Countries; Fr, France; Al, Alps; Du, Durance; Lo, Loire; Rh, Rhône; LB, Les Brocs; M, Mallemort; Po, Pouilly; Ti, Tinte; 1-4, zones $1-4$ in Tinte. set of genotypes over which gene diversities is estimated is subdivided into subpopulations with different allele frequencies, gene diversity estimated with mean allele frequencies is greater than the mean of gene diversities in the different subdivisions; this effect on estimates is similar to the Wahlund effect. Separate computation of $H$ for young and old trees showed, however, high values of $H$ in the two age classes $(H=0.192$ for the young and 0.171 for the old), showing that the computation effect is not the only reason for the high observed diversity.

Comparing the zones of Tinte, there are differences in allele frequencies, e.g. for the loci $I d h-1$ and Est-r, although the diversity index is very homogeneous between zones $(0.143-0.147)$, and is not different from the global index of the stand (0.148). Analysis of genetic distances shows overlapping ranges of distances between zones of the same stand and between stands. Zone 4 of Tinte is closer to Mallemort than to other zones of Tinte. On the other hand, the two apparent age classes in Les Brocs are closer to each other than to any other stand, although displaying an important distance between themselves.

\section{Hardy-Weinberg equilibrium}

The geographical groups at the different hierarchical levels were found to be at HWE for a significance threshold of 5 per cent, except the stand Les Brocs $(P$-value $=0.0167)$. In this stand, HWE was tested on both age classes: a significant deviation was found only for the young.
Fig. 4 Genetic distances between geographical groupings of the Populus nigra collection: (a) between regions, coancestry distance; (b) between stands, coancestry distance; (c) between regions, Gregorius distance; (d) between stands, Gregorius distance. (a)

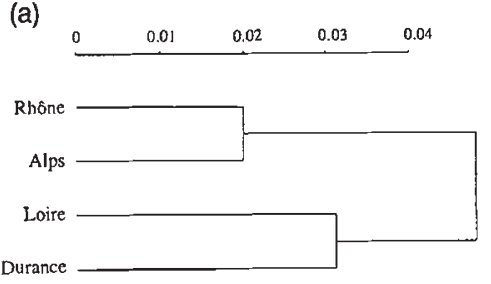

(c)

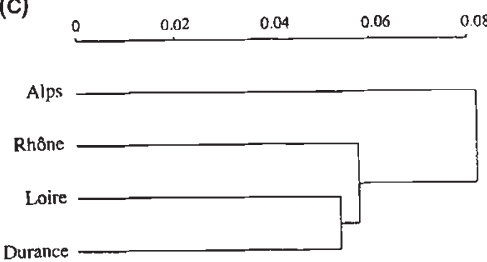

(b)

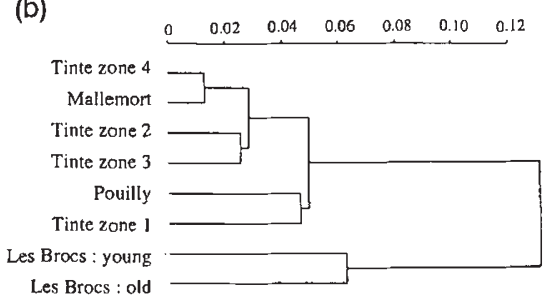

(d)

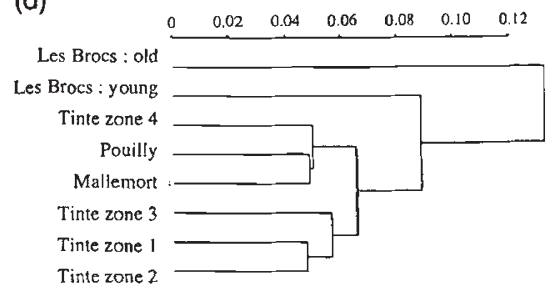




\section{Differentiation}

Computation of $\theta$ and its variance (Table 1) with Weir \& Cockerham's estimator showed widely overlapping confidence intervals for the three hierarchical levels. Values greater than 0.01 suggest, according to Chakraborty \& Leimar (1987), that Nei $\&$ Chesser's $G_{\mathrm{ST}}$ estimation should be better. The small $G_{\mathrm{ST}}$ values $(0.017,0.035$ and 0.008$)$ reflect a low differentiation. Although differences are not significant, the highest level of differentiation was found between stands within the Loire drainage.

\section{Discussion}

\section{Choice of descriptors for natural populations}

Natural populations of diploid individuals are described and compared to each other using parameters derived from genetic models, in which deviations from the HWE reference state are measured. But the sampling requirements concerning individuals and loci, and many different sources of discrepancies between real and model populations, like nonrandom mating, overlapping generations and historical events (e.g. bottlenecks), make the estimation of the parameters difficult. This leads to the use of various estimators, which makes comparison between studies difficult. Indeed, according to Chak- raborty \& Leimar (1987), variation in the estimations of $H$ arising from the sampling of loci is greater than variation arising from the sampling of individuals, so that studies involving different loci may be difficult to compare. Weir (1990) proposes estimations of the parameters and their variances that take into account nonrandom mating, unequal sample sizes and sampling of loci, allowing the comparison between different studies. However, it is difficult to determine to what extent the properties of real populations diverge from the underlying model hypotheses (little is known about genetic exchanges between populations and about fluctuations in the population sizes), and to what extent the model is robust to such deviations.

Different reviews (e.g. Hamrick \& Godt, 1989) give average values of the diversity and differentiation parameters, obtained with simple, noncorrected estimations over many studies, for categories of species. In fact, the computation of averages limits the variation because of the use of different estimators, so that such averages may be compared to the results of our particular study.

Because vegetative propagation is not included in the models used to derive the descriptors, the high ability for vegetative propagation observed in some particular stands of $P$. nigra was suspected to be another possible alteration of their significance: yet

Table 1 Differentiation parameters over the three hierarchical levels in the Populus nigra collection: simple estimates, Nei \& Chesser estimates and Weir \& Cockerham estimates

\begin{tabular}{|c|c|c|c|}
\hline & Regions within France & $\begin{array}{l}\text { Stands within } \\
\text { the Loire valley }\end{array}$ & $\begin{array}{l}\text { Zones within } \\
\text { the stand Tinte }\end{array}$ \\
\hline \multicolumn{4}{|c|}{ Simple estimates } \\
\hline$H_{\mathrm{S}}$ & 0.171 & 0.162 & 0.140 \\
\hline$H_{\mathrm{T}}$ & 0.177 & 0.169 & 0.145 \\
\hline$G_{\mathrm{ST}}$ & 0.036 & 0.044 & 0.035 \\
\hline \multicolumn{4}{|c|}{ Nei and Chesser estimates } \\
\hline$H_{\mathrm{S}}$ & 0.175 & 0.164 & 0.145 \\
\hline$H_{\mathrm{T}}$ & 0.178 & 0.170 & 0.147 \\
\hline$G_{\mathrm{ST}}$ & 0.017 & 0.035 & 0.008 \\
\hline \multicolumn{4}{|c|}{$\begin{array}{l}\text { Weir and Cockerham estimates } \\
\text { (bootstrap confidence interval) }\end{array}$} \\
\hline \multirow[t]{2}{*}{$\theta$} & 0.033 & 0.063 & 0.025 \\
\hline & $\left(\begin{array}{ll}0.020 & 0.0471\end{array}\right)$ & $\left(\begin{array}{ll}0.006 & 0.119\end{array}\right)$ & $\left(\begin{array}{ll}0.019 & 0.031\end{array}\right)$ \\
\hline \multirow[t]{2}{*}{$f$} & 0.201 & 0.113 & -0.051 \\
\hline & $\left(\begin{array}{ll}0.070 & 0.333\end{array}\right)$ & $\left(\begin{array}{ll}-0.068 & 0.294\end{array}\right)$ & $\left(\begin{array}{ll}-0.148 & 0.046\end{array}\right)$ \\
\hline \multirow[t]{2}{*}{$F$} & 0.025 & 0.159 & -0.0218 \\
\hline & $\left(\begin{array}{ll}0.019 & 0.031\end{array}\right)$ & $\left(\begin{array}{ll}-0.041 & 0.358\end{array}\right)$ & $\left(\begin{array}{ll}-0.116 & 0.073\end{array}\right)$ \\
\hline
\end{tabular}

For the simple and Nei \& Chesser estimates, $G_{\mathrm{ST}}=1-\left(H_{\mathrm{S}} / H_{\mathrm{T}}\right)$ where $H_{\mathrm{S}}$ is the expected heterozygosity of one individual in any subpopulation and $H_{\mathrm{T}}$ is the expected heterozygosity of one individual in the whole population, both under the panmixia hypothesis. 
in another study (Legionnet et al., in prep.), we show that most of the adult stands of $P$. nigra originated from seedlings.

\section{Comparison with other species}

Genetic diversity for $P$. nigra $(H=0.17)$ is very close to the mean for forest trees $(H=0.15)$ and to the mean for wide-ranged species $(H=0.20)$ (Hamrick \& Godt, 1989); it is less than for the North American forest poplar $P$. tremuloides $(H=0.29$, Jelinski \& Cheliak, 1992; $H=0.22$, Lund et al., 1992), and more than for $P$. trichocarpa, another riparian poplar species $(H=0.096$, Weber \& Stettler, 1981). The between-stands and between-regions differentiations of $P$. nigra (3.5 per cent and 1.7 per cent, respectively) are smaller than the average values for longlived woody species and for outcrossing, wind-pollinated species ( 7.6 per cent and 9.9 per cent, respectively), but are close to the mean differentiation of tree species with large and continuous distributions (3 per cent) (Kremer, 1994). For most tree species, this low differentiation can be explained by high dispersion rates that ensure enough migration to avoid differentiation. Populus nigra can be compared to species with a continuous range, although its range is mainly in riparian forest, because of the presence of scattered trees and small stands in perturbed upland sites, and because of human propagation of ornamental $P$. nigra clones, which allow the species to function as a large continuum.

\section{Spatial variations of gene diversity: inter-regional scale}

The highest diversity found over the regions is in the Alps region. Because of the large confidence interval computed for this region, the high observed diversity may result from chance. Nevertheless, in this region, mountains constitute physical obstacles to gene flow: limitation of gene flow and subsequent isolation of populations, as well as founder effect in the settlement of colonies in extreme conditions could lead to local differentiation. A high level of diversity would then be explained by the fact that the estimation of $H$ was made over heterogeneous populations. Considering that diversity in the Alps is close to that found in the foreign countries collection, and that the Alps are the sampled region closest to the centre of the species range, another hypothesis could be that France, representing a margin of the species range, is impoverished in terms of diversity, except in its most central region. In contrast to the other regions, sampling of genotypes in the Alps was made by collecting seeds instead of adult trees, and this may be an artificial cause of the high level of gene diversity detected.

\section{Differentiation and local allele fixation}

In this survey, only 1.7 per cent of the total diversity is between regions. But this low differentiation does not take into account the heterogeneous distribution of alleles: $M D H-1-1$ was not found in the Loire river sample, $S D H-3$ is a fixed allele in Mallemort. Although low $G_{\mathrm{ST}}$ (or $\theta$ ) values are usually thought to result from large-scale gene flow, the local allele fixation observed in this study suggests that migration may not be sufficient to homogenize regions. To explain these results, we suggest that the low differentiation could remain from an ancient state of the species: indeed, this species is a pioneer, and recolonization of Europe and Asia by trees after the last glaciation probably started with a wide spreading of pioneer species. The distribution of the species may then have been more continuous, allowing greater genetic exchange. Later appearance of discontinuities in the species range and subsequent isolation of populations could explain local fixation of some alleles by genetic drift. The small number of generations since isolation could be invoked to explain the fact that for most loci, the most frequent allele is the same in all geographical groups. Another explanation for the low differentiation is that the populations are quite isolated, leading to local fixation or loss of alleles, but the wide distribution of a small number of vegetatively propagated man-used genotypes leads to the wide distribution of some alleles in natural populations, and this is enough to avoid differentiation as described by $G_{\mathrm{ST}}$. As a matter of fact, $P$. nigra var. italica has been very popular since the XVIIIth century (Bugala, 1967), and is still very frequently planted.

\section{Spatial variations of gene diversity: intraregional scale}

The comparison of gene diversities in the different stands shows the individuality of two neighbouring stands from the Loire river valley: Les Brocs and Pouilly. Les Brocs has the highest diversity among stands (and it proved not to be caused by the presence of two age classes), and Pouilly has the lowest. However, the estimation variance of the gene diversity is high, and these differences are not significant. These stands are differentiated slightly by their ecological characteristics. Pouilly corresponds 
to a later degree of evolution of the riparian forest, although the trees are younger than the old trees in Les Brocs. This last site could have been maintained at a younger ecological stage by human activity and perturbations caused by floods. Temporal variation in the environment of a long-lived, sessile organism may require genetic flexibility, so that large individual degrees of heterozygosity may be favoured in ageing stands. This could be invoked to explain the high gene diversity in Les Brocs. By contrast, the gene diversity is very low in Pouilly: this could be explained by a switch in natural selection between almost monospecific stands, like Les Brocs, and mixed stands like Pouilly, heterozygosity being less favoured in mixed stands. But it is also possible that surviving trees in Pouilly are not representative of the former stand and that the natural sampling of trees during the evolution of the stand led randomly to low gene diversity.

\section{Spatial variations of gene diversity: intrastand scale}

Genetic distances reveal a great similarity between zones of the same stand, especially in Les Brocs. But the ecological characteristics of the species do not ensure genetic resemblance between zones: the seeds are produced in great quantities and over a long period of time within one stand (Legionnet et al. in prep.), and wide dispersal is assured by the abundant and light hydrophobic poplar cotton. Few reserves are carried by seeds, which do not have a long viability (2-4 weeks; Muller \& Teissier du Cros, 1982). Therefore, the composition of the seed pool will vary greatly from one day to another in a given site; settlement of seedlings only occurs in particular conditions of ground and water availability, which depend on local events (persistence of a puddle) and are rare at a given site. For these reasons, neighbouring sites can be colonized by seed pools of different origins. Yet, allelic composition and diversity were found to be homogenous between age classes in Tinte and in Les Brocs. This could be caused by global homogeneity of the sources of seedlings, or by a good mixing of seeds of different origins. Young zones could also be colonized by a majority of seeds coming from the older neighbouring trees, and thus reflect their allelic composition. Another hypothesis is that apparently younger trees found closer to the river settled at the same time as the older, but were often cut back by perturbation caused by floods, so that the apparent age does not reflect the time after settlement.

\section{Conclusion}

Populus nigra plays an important role in riparian forests. Conservation of genetic resources is important to enable the species to evolve, which also conditions the evolution of the whole ecosystem. Besides, genetic resources will be useful for producing new commercial hybrids. The main danger for this species is the reduction of its natural area that can lead to the loss of natural populations in some regions. The conservation of riparian ecosystems is a difficult task, which may take a long time. The first step in genetic conservation is the constitution of an ex situ collection representative of the available gene diversity. This first study of the natural variation of the species reveals a fair level of diversity and a low overall differentiation, masking, however, some differences between regions.

A sampling strategy based on gene diversity will not need to include many regions, because most of the gene diversity is intraregional; the sample would be improved by the addition of provenances from the east and from foreign countries; the collection sites representing younger stages of the ecosystem seem likely to provide more diversity. A strategy aimed at catching favourable alleles for breeding should, however, be based on a study of different regions, because limited gene flow may allow differentiation for naturally selected traits.

\section{Acknowledgements}

This work was supported by a grant of the 'Direction de l'Espace Rural et de la Forêt, Ministère de l'Agriculture et de la Forêt'. We thank the technical team which took care of the trees in the nursery. We thank two anonymous reviewers who made useful comments on the first manuscript.

\section{References}

BERGMANN, F. 1987. Characterization of multiclonal aspen cultivars using isozyme electrophoresis. For. Ecol. \& Manag., 22, 167-172.

Bugala, w. 1967. Populus nigra L. Arboretum Kornickie, 12, $1-220$.

CAgelli, L. \& Lefevre, F. 1995. Conservation of Populus nigra L. and gene flow with cultivated poplar species in Europe. Forest Genet., in press.

CHAKRABORTY, R. AND LEIMAR, o. 1987. Genetic variation within a subdivided population. In: Ryman, N. and Utter, F. (eds) Population Genetics and Fishery Management, pp. 89-120. University of Washington Press, Seattle.

Clayton, J. W. AND TRETIAK, D. N. 1972. Amine-citrate 
buffers for control in starch gel electrophoresis. J. Fish. Res. Board Can., 29, 1169-1172.

Duval, H., Duval, O. AND LeFÈVRe, F. 1993. Collection ex situ Populus nigra $L$. INRA, Orléans.

FRISON, E., LEFÈVRE, F., DE VRIES, S. AND TUROK, J. 1995. Populus nigra network. Report of the first meeting, 3-5 Oct. 1994, Izmit, Turkey.

FUERst, P. A., CHAKRABORTY, R. AND NEI, M. 1977. Statistical studies on protein polymorphism in natural populations. I. Distribution of single locus heterozygosity. Genetics, 86, 455-483.

GREGORIUS, H.-R. 1974. Genetischer Abstand zwischen Populationen. I. Zur Konzeption der genetischen Abstandsmessung. Silvae Genet., 23, 22-27.

Gregorius, H.-R. 1984. A unique genetic distance. Biom. $J .$, 26, 13-18.

GUO, s. W. AND THOMPSON, E. A. 1992. Performing the exact test of Hardy-Weinberg proportion for multiple alleles. Biometrics, 48, 361-372.

HAMRICK, J. L. AND GODT, M. J. w. 1989. Allozyme diversity in plant species. In: Brown, A. H. D., Clegg, M. T., Kahler, A. L. and Weir, B. S. (eds) Plant Population Genetics, Breeding, and Genetic Resources, pp. 43-63. Sinauer Associates, Sunderland, MA.

JELINSKI, D. E. AND CHELIAK, w. M. 1992. Genetic diversity and spatial subdivision of Populus tremuloides (Salicaceae) in a heterogeneous landscape. Am. J. Bot., 79, $728-736$.

KREMER, A. 1994. Genetic diversity and phenotypic variability of forest trees. Génét. Sél. Évol., 26 (Suppl. 1), $105-123$.

LEFORT-BUSON, M. AND DE VIENNE, D. 1985. Les Distances Génétiques. Estimations et Applications. INRA Editions, Paris.

LOUIS, E. J. AND DEMPSTER, E. R. 1987. An exact test for Hardy-Weinberg and multiple alleles. Biometrics, 43, $805-811$.

LUND, s. T., FURNIER, G. R. AND MOHN, C. A. 1992. Isozyme variation in quaking aspen in Minnesota. Can. J. Forest Res., 22, 521-524.

MAlvolti, M. E., BOCCONE, A., FINESCHI, S. AND PACIUCCI, M. 1991 Marcatori biochimici nella tassonomia del pioppo. Monti e Boschi, 1, 49-56.

MULlER, C. AND TEISSIER DU CROS, E. 1982. Conservation pendant cinq ans de graines de peupliers noirs (Populus nigra L.). Ann. Sci. Forest., 39, 179-185.

NEI, M. 1972. Genetic distance between populations. Am. Nat., 106, 283-292.
NEI, M. 1973. Analysis of gene diversity in subdivided populations. Proc. Natl. Acad. Sci. U.S.A., 70 , 3321-3323.

NEI, M. AND CHESSER, R. K. 1983 Estimation of fixation indices and gene diversities. Ann. Hum. Genet., 47, 253-259.

RAJORA, O. P. 1990. Genetics of allozymes in Populus deltoides Marsh., $P$. nigra, L. and $P$. maximowiczii Henry. J. Hered., 81, 301-308.

RAYMOND, M. AND ROUSSET, F. 1995. GENEPOP (version 1.2): population genetics software for exact tests and eucumenicism. J. Hered., 86, 248-249.

REYNOLDS, J., WEIR, B. S. AND COCKERHAM, C. C. 1983. Estimation of the coancestry coefficient: basis for a short-term genetic distance. Genetics, 105, 767-779.

SCANDALIOS, J. G. 1969. Genetic control of multiple molecular forms of enzymes in plants: a review. Biochem. Genet., 3, 37-79.

SECOND, G. AND TROUSLOT, P. 1980. Electrophorèse d'enzymes du riz (Oryza sp.). Travaux et documents de l'ORSTOM, Paris.

SPRENT, P. 1992. Pratique des Statistiques non Paramétriques. Techniques et Pratiques. INRA Editions, Paris.

SWOFFORD, D. L. AND SELANDER, R. B. 1981. BIOSYS-1. A FORTRAN program for the comprehensive analysis of electrophoretic data in population genetics and systematics. J. Hered., 72, 281-283.

TEISSIER DU CROS, E. 1977. Aperçu de la transmission héréditaire de quelques caractères juvéniles chez Populus nigra L. Ann. Sci. For, 34, 311-322.

VIART, M. 1992. Présentation du Catalogue International des cultivars de Peupliers. In: Padro, A. (ed.) Proceedings of the 19th Session of the International Poplar Commission, 22-25 IX 1992, Zaragoza.

WEBER, J. C. AND STETTLER, R. F. 1981. Isozyme variation among ten populations of Populus trichocarpa Torr. et Gray in the Pacific Northwest. Silvae Genet., 30, 82-87.

WEIR, B. S. 1990. Genetic Data Analysis. Sinauer Associates, Sunderland, MA.

WEIR, B. S. AND COCKERHAM, c. c. 1984 . Estimating $F$-statistics for the analysis of population structure. Evolution, 38, 1358-1370.

WRIGHT, s. 1940. Breeding structure of populations in relation to speciation. Am. Nat., 74, 232-248.

WRIGHT, s. 1951. The genetical structure of populations. Ann. Eugen., 15, 323-354.

zsuffa, L. 1974. The genetics of Populus nigra L. Annales Forestales, 6, 29-49. 